\title{
PENGARUH PERBANDINGAN SARI BUAH DAN GULA TERHADAP MUTU MINUMAN FUNGSIONAL LABU KUNING
}

\section{The Influence of Juice and Sugar Ratio on The Quality of Functional Drink of Pumpkin}

Kamsina*, Inda Three Anova, dan Firdausni

Balai Riset dan Standardisasi Industri Padang

JI. Raya LIK No. 23 Ulu Gadut, Padang 25164

*e-mail: kamsinaina@gmail.com

\begin{abstract}
ABSTRAK
Minuman fungsional dihasilkan dari pengolahan buah untuk dikonsumsi secara langsung. Minuman ini diperoleh melalui proses pencucian, penghancuran, penjernihan (jika dibutuhkan), pasteurisasi, fermentasi, dan pengemasan. Minuman fungsional labu kuning bisa digunakan sebagai pemuas rasa dan berfungsi khusus untuk menambah asupan vitamin dan mineral tertentu, meningkatkan stamina tubuh, dan mengurangi resiko penyakit tertentu (seperti antioksidan untuk mengurangi resiko kanker). Tujuan penelitian ini adalah menentukan konsentrasi juice labu kuning dan konsentrasi gula yang optimal dalam pembuatan minuman fungsional labu kuning. Hasil penelitian menunjukkan bahwa perlakuan rasio sari labu kuning dengan air 1:1 dan penambahan gula pasir 20\% (A1B3) memberikan hasil terbaik terhadap nilai $\mathrm{pH}$, kadar gula, total asam, total padatan terlarut, cemaran logam dan jumlah bakteri asam laktat. Untuk semua perlakuan, cemaran mikroba hasilnya bagus, baik bakteri koliform <2 APM/100 ml (negatif) maupun salmonella (negatif) serta memiliki ketahanan simpan pada suhu $4^{\circ} \mathrm{C}$ (refrigerator) selama 3 (tiga) minggu.
\end{abstract}

\section{Kata Kunci: Labu kuning, sari buah, gula}

\section{ABSTRACT}

Functional beverage is a kind of beverage obtained from the edible part of a fruit through process of washing, crushing, and purifying (if required), pasteurizing, fermenting, and packaging to be consumed immediately. Functional drinks of pumpkin can be used as a satisfying taste and have special function to increase the certain vitamins and minerals intake, increasing stamina, and reducing the risk of certain diseases (such as antioxidants to reduce the risk of cancer). The purpose of this study was to determine the optimum concentration of pumpkin juice and sugar concentration in making of functional drinks of pumpkin. The results showed that the treatment variation of pumpkin juice and water ratio $1: 1$ and the addition of sugar $20 \%$ (A1B3) provided the best results for $\mathrm{pH}$, sugar content, total acid, total dissolved solid, metal contamination, and the amount of lactic acid bacteria. For all treatments, the results of microbial contamination were good, both coliforms <2 APM/100 ml (negative) and salmonella (negative), and had storage resistance at a temperature of $4^{\circ} \mathrm{C}$ (refrigerator) for three (3) weeks.

\section{Keywords: Pumpkin, juice, sugar}

\section{PENDAHULUAN}

Tanaman labu kuning dapat tumbuh di dataran rendah maupun dataran tinggi sehingga cocok juga tumbuh di Sumatera Barat, khususnya kabupaten Solok, Agam dan Tanah Datar memiliki potensi labu kuning yang cukup besar. Kabupaten Solok menurut data Sumbar dalam Angka tahun 2011, areal tanam mencapai 45 ha dengan total produksi 1.025 ton. 
Labu kuning atau waluh merupakan bahan pangan yang kaya vitamin $A, B$, dan $C$, mineral, serta karbohidrat namun labu kuning tidak tinggi kalori sehingga tidak mengkhawatirkan bagi yang sedang diet rendah kalori. Dalam 100 gram labu kuning hanya mengandung 29 kalori sehingga cukup aman dikonsumsi walaupun sudah diberi beberapa bahan penunjang seperti tepung terigu atau beras. Labu kuning juga sangat baik untuk menu diet rendah lemak juga sebagai obat alternatif, seperti untuk pengobatan gangguan kesuburan, reaksi alergi, gangguan kantung kemih, mengatasi diabetes dan hipertensi (Yuliani et al, 2003).

Selain mengandung kalori, labu kuning juga mengandung $1,1 \mathrm{~g}$ protein, lemak $0,3 \mathrm{~g}$, karbohidrat $6,6 \mathrm{~g}$, mineral kalsium, fosfor, zat besi, mangan dan magnesium serta vitamin A, B dan C (Sushanty, 2013). Selain itu daging buah labu kuning mengandung antioksidan yang berfungsi sebagai penangkal jenis kanker yang bermanfaat bagi kesehatan dan dapat dimanfaatkan dalam pangan fungsional (Widawati, 2000).

Pada dasarnya, minuman fungsional termasuk dalam salah satu jenis pangan fungsional. Sebagai pangan fungsional, minuman fungsional tentunya harus sudah memenuhi dua fungsi utama pangan yaitu memberikan asupan gizi pemuasan sensori seperti rasa yang enak dan tekstur yang baik, serta mempunyai fungsi nilai fungsionalnya seperti menjadi regulasi boritme, sistem imunitas, sistem saraf dan pertahanan tubuh. Minuman biasa menawarkan kita kebutuhan terhadap air dan sebagai pemuas rasa, tetapi untuk minuman fungsional dilengkapi dengan fungsi tersier seperti probiotik, menambah asupan vitamin dan mineral tertentu, meningkatkan stamina tubuh dan mengurangi resiko penyakit tertentu (seperti: antioksidan untuk mengurangi resiko kanker) (Rezawidya, 2011).

Sifat fungsional dalam makanan fungsional disebabkan oleh adanya komponen bioaktif yang terdapat dalam bahan nabati (misalnya serat pangan, inulin, FOS dan antioksidan) ataupun bahan hewani (EPA, DHA dan CLA). Sifat fungsional juga bisa disebabkan oleh adanya mikroorganime yang memiliki sifat menguntungkan di dalam sistem pencernaan, misalnya probiotik (Naidu dan Clemens, 2000).

Probiotik menurut FAO/WHO (2002) adalah mikroorganisme hidup yang masuk dalam jumlah yang cukup sehingga dapat memberikan manfaat kesehatan bagi inang. Jumlah yang cukup adalah 106-108 cfu/g dan diharapkan dapat berkembang menjadi $1012 \mathrm{cfu} / \mathrm{g}$ di dalam kolon. Probiotik juga dapat menghambat bakteri patogen, melakukan metabolisme terhadap laktosa sehingga bermanfaat bagi penderita intoleran laktosa (Rusilanti, 2006). Efek positif dari konsumsi probiotik bagi kesehatan adalah mencegah diare karena dapat melawan rotavirus, menstimulasi sistem imun, mencegah pembengkakan usus (irritable bowel diseases), memberi manfaat bagi penderita intoleran laktosa, membantu mengatasi alergi, menurunkan resiko kanker, mencegah infeksi patogen di saluran pernapasan, mencegah konstipasi, dan menurunkan kadar kolesterol.

Roberfroid (2002) menambahkan bahwa minuman fungsional harus berupa bahan pangan, bukan berupa pil atau kapsul, dan manfaatnya harus bisa dirasakan apabila dikonsumsi secara normal dalam bahan pangan. Dari sisi teknis, pangan fungsional dapat berupa: (1) Bahan pangan alami, (2) Bahan pangan yang telah ditambah komponen tertentu, (3) Bahan pangan yang telah dihilangkan kandungan komponen tertentu, (4) Bahan pangan yang fungsi biologis dari satu atau beberapa komponennya telah dimodifikasi, dan (5) Bahan pangan dengan kombinasi dari ciriciri tersebut.

Dalam pembuatan minuman sari buah fungsional selain buah, juga dibutuhkan pemakaian gula. Gula adalah suatu karbohidrat sederhana yang menjadi sumber energi dalam minuman sari buah. Gula paling banyak diperdagangkan dalam bentuk kristal sukrosa padat. Gula digunakan untuk mengubah rasa menjadi manis pada makanan atau minuman. Gula sederhana, seperti glukosa (yang diproduksi dari sukrosa dengan enzim atau hidrolisis asam), menyimpan energi yang akan digunakan oleh sel (Anonim, 2012).

Gula sebagai sukrosa diperoleh dari nira tebu, bit gula, atau aren. Meskipun demikian, terdapat sumber-sumber gula 
minor lainnya, seperti kelapa. Sumbersumber pemanis lain, seperti umbi dahlia, anggur, atau jagung, juga menghasilkan semacam gula/pemanis namun bukan tersusun dari sukrosa. Proses untuk menghasilkan gula mencakup tahap ekstrasi (pemerasan) diikuti dengan pemurnian melalui distilasi (penyulingan) (Suprayatmi, 1996).

Secara kimiawi gula sama dengan karbohidrat, tetapi umumnya pengertian gula mengacu pada karbohidrat yang memiliki rasa manis, berukuran kecil dan dapat larut. Istilah gula biasanya digunakan untuk menyatakan sakarosa (sukrosa). Gula merupakan karbohidrat yang memiliki rasa manis, berukuran kecil dan dapat larut (dalam air).

Rasa manis yang biasa dijumpai pada tanaman terutama disebabkan oleh tiga jenis gula, yaitu sakarosa, fruktosa dan glukosa. Gula-gula ini berada secara sendirisendiri ataupun dalam bentuk campuran satu dengan yang lain. Madu merupakan larutan yang terdiri dari glukosa, fruktosa dan sakarosa dalam air, dengan komposisi sekitar $80 \%$ gula dan $20 \%$ air. Komposisi gula pada tanaman dipengaruhi juga oleh asal tanaman. (Anonim, 2009).

Suprayatmi (1996) menyatakan bahwa gula pasir sebagai gula sukrosa merupakan gula dari sari tebu yang mengalami proses kristalisasi. Warnanya ada yang putih dan kecoklatan (raw sugar). Karena ukuran butirannya seperti pasir, disebut gula pasir. Biasanya digunakan sebagai pemanis untuk masakan,minuman, kue atau penganan lain.

Muchtadi (2001) menyatakan bahwa dalam pembuatan sari buah dibutuhkan bahan pemanis atau gula pasir sebanyak $15 \%$. Labu kuning sangat kaya dengan $\beta$ karoten, vitamin $\mathrm{C}$ dan antioksidan serta miniral.

Selama ini belum ada minuman fungsional dari labu kuning dilakukan, oleh sebab itu maka perlu dilakukan penelitian "Pengaruh Perbandingan Sari Buah dan Gula terhadap Mutu Minuman Fungsional Labu Kuning" untuk mendapatkan produk minuman yang baik dan sehat. Tujuan penelitian ini adalah menentukan konsentrasi juice labu kuning dan konsentrasi gula yang optimal dalam pembuatan minuman fungsional labu kuning

\section{METODOLOGI PENELITIAN}

Bahan yang diperlukan adalah labu kuning, gula pasir, starter, susu kambing, ethanol $70 \%$, kemasan, aquadest, kain saring, lem label, bahan bakar serta bahan kimia untuk pengujian seperti Pepton Water, Lactose Broth, Brilliant Green Lactose Broth dan Natrium Agar, $\mathrm{NaOH}$, methanol. Sedangkan Peralatan yang digunakan meliputi; neraca analitik, oven listrik, furnace, autoklaf, inkubator, laminar flow cabinet dan HPLC.

\section{Rancangan Penelitian}

Rancangan yang dilakukan adalah Rancangan Acak Lengkap (RAL) secara faktorial dengan perlakuan $A$. variasi perbandingan sari labu kuning dengan air $(1: 1 ; 1: 2$; dan $1: 3)$, dan $B$ konsentrasi gula pasir (10\%, 15\% dan 20\%). Masing-masing perlakuan dilakukan dengan 3 kali ulangan. Data yang di-peroleh diolah secara statistik dengan uji lanjutan metoda DNMRT pada taraf nyata $5 \%$.

\section{Pelaksanaan Penelitian}

Labu kuning dikupas, dicuci sampai bersih serta dilakukan pengecilan ukuran dengan cara pemotongan. Setelah dilakukan penimbangan, potongan labu kuning diblansing lebih kurang 5 (lima) menit dan dilakukan penghancuran dengan menggunakan blender dengan penambahan air sesuai dengan perlakuan. Bubur labu kuning yang didapatkan disaring, dilakukan penambahan gula sesuai perlakuan dan dipasteurisasi pada susuh $80^{\circ} \mathrm{C}$ serta dinginkan sampai suhu $40^{\circ} \mathrm{C}$. Setelah mencapai suhu $40^{\circ} \mathrm{C}$, dilakukan penambahan starter, serta diinkubasi dalam inkubator dengan suhu $36^{\circ} \mathrm{C}$ selama 18 jam. Minuman fungsional labu kuning dikemas dalam kemasan cup tertutup dan disimpan dalam refrigerator. 


\section{Analisis}

Analisis kimia yang dilakukan terhadap produk minuman fungsional labu kuning yakni $\mathrm{pH}$ dengan $\mathrm{pH}$ meter, kadar gula dengan titrasi, total asam (dihitung sebagai asam laktat), total padatan terlarut secara gravimetri dan cemaran logam $\mathrm{Fe}$ dengan Atomic Adsortion Spectrophotometry (AAS), dan pengujian mikrobiologi meliputi bakteri asam laktat metoda kuantitatif, bakteri koliform metoda Angka Paling Mungkin (APM) dan Salmonella metoda kualitatif.

Ketahanan simpan dilakukan terhadap pertumbuhan bakteri koliform selama 3 minggu penyimpanan pada suhu $5-10^{\circ} \mathrm{C}$ dalam refrigerator dengan kemasan cup yang tertutup rapat.

\section{HASIL DAN PEMBAHASAN}

\section{Nilai pH}

$\mathrm{pH}$ atau derajat keasaman digunakan untuk menyatakan tingkat keasaaman atau basa yang dimiliki oleh suatu zat, larutan atau benda. Perlakuan konsentrasi sari buah labu kuning dan konsentrasi gula terhadap mutu minuman fungsional labu kuning memberikan hasil yang berpengaruh sangat nyata terhadap nilai $\mathrm{pH}$ minuman fungsional labu kuning.

Hasil analisa terhadap $\mathrm{pH}$ menunjukkan bahwa variasi perlakuan perbandingan sari labu kuning dengan air 1:3 dan konsentrasi gula pasir $10 \%$ memberikan hasil tertinggi dengan nilai $\mathrm{pH} 3,73$ (A3B1). Hal ini berbeda nyata dengan perlakuan lainnya tapi tidak berbeda dengan perlakuan A3B2, sedangkan perlakuan A1B3 (perbandingan sari buah dengan air 1:1 dan penambahan gula pasir $20 \%$ ) memberikan nilai $\mathrm{pH}$ terendah yaitu 3,53 tidak berbeda dengan perlakuan A1B2. Adapun hasil nilai pH dapat dilihat pada Gambar 1.

Adanya pengenceran dalam proses pembuatan minuman fungsional labu kuning dapat mempengaruhi nilai $\mathrm{pH}$ produk. Hal ini disebabkan nilai $\mathrm{pH}$ air yang normal adalah netral sekitar 6-8, sehingga semakin tinggi kadar air dalam sari buah maka akan semakin meningkatkan $\mathrm{pH}$ minuman fungsional labu kuning yang dihasilkan (Rahman, 1989). Akan tetapi setelah adanya proses fermentasi menyebabkan $\mathrm{pH}$ mengalami penurunan yang diduga terjadi akibat terpakainya gula sebagai nutrisi yang dimanfaatkan oleh bakteri asam laktat untuk melakukan metabolisme selama fermentasi. Penurunan $\mathrm{pH}$ merupakan salah satu akibat dari proses fermentasi yang terjadi karena adanya akumulasi asam laktat dan asam organik. Lactobacillus dapat menurunkan $\mathrm{pH}$ lingkungan dengan mengubah gula menjadi asam laktat. Kondisi ini akan menghambat pertumbuhan beberapa jenis bakteri patogen (Obermen et al, 1998).

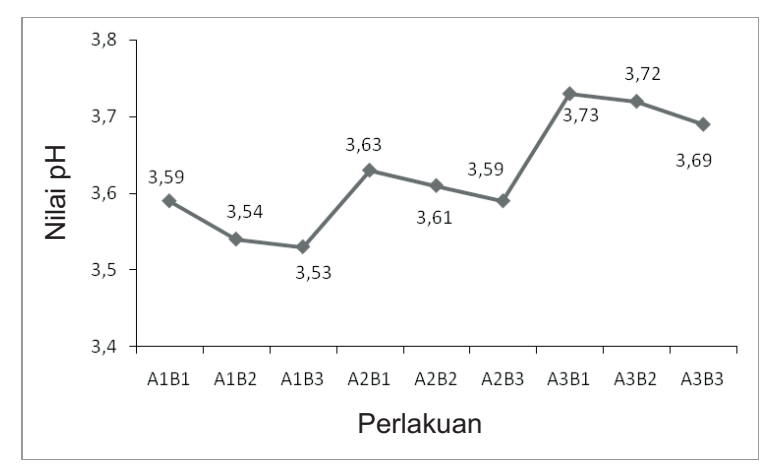

Gambar1. Pengaruh pengenceran konsentrat sari buah labu kuning dan konsentrasi gula terhadap $\mathrm{pH}$ minuman fungsional labu kuning

Dari hasil analisa juga dapat dilihat bahwa dengan meningkatnya konsentrasi gula menyebabkan semakin rendahnya nilai $\mathrm{pH}$ yang didapat. Hal ini sesuai dengan pernyataan Widowati dan Misgiyarta (2003) bahwa semakin banyak gula yang terdapat pada substrat, maka semakin banyak glukosa yang dimetabolisme sehingga produksi asam laktat lebih tinggi. Jumlah asam laktat yang tinggi dapat meningkatkan keasaman dan menurunkan $\mathrm{pH}$ substrat.

\section{Kadar Gula}

Hasil analisa Kadar gula dari minuman fungsional labu kuning menunjukkan bahwa semua perlakuan berpengaruh terhadap kadar gula. Adapun hasilnya dapat dilihat pada Gambar 2.

Berdasarkan Gambar 2 dapat dilihat bahwa kadar gula minuman fungsional dari labu kuning berkisar antara 14,20\% $15,85 \%$. Kadar gula tertinggi didapatkan 
pada rasio sari labu kuning dengan air 1:1 dan perlakuan penambahan konsentrasi gula 20\% (A1B3) memberikan hasil tertinggi dengan total gula $15,85 \%$ yang benda nyata dengan perlakuan lainnya. Sedangkan kadar gula terendah didapatkan pada perlakuan A3B1 dengan nilai $14,20 \%$.

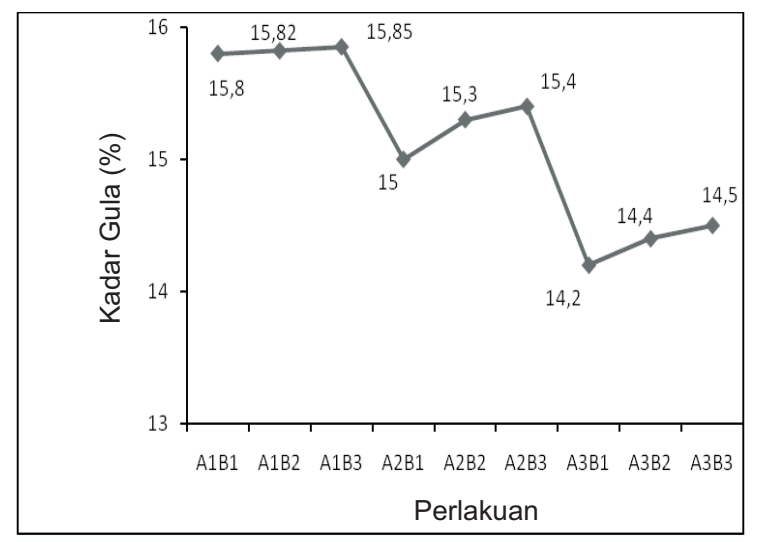

Gambar2. Pengaruh pengenceran konsentrat sari buah labu kuning dan konsentrasi gula terhadap kadar gula minuman fungsional labu kuning

Total gula yang terdapat dalam sari minuman fungsional labu kuning dimanfaatkan oleh bakteri asam laktat (BAL) dalam proses metabolis me pertumbuhannya. Pada proses fermentasi terjadi metabolisme bakteri yang menggunakan glukosa sebagai nutrisi pertumbuhannya, kemudian glukosa tersebut diubah menjadi asam laktat. Sehingga total gula mengalami penurunan. Semakin lama waktu fermentasi, maka jumlah bakteri asam laktat meningkat. Sehingga mempengaruhi seberapa besar total gula yang dirombak menjadi asam (Retnowati et al., 2014).

\section{Total Asam}

Keasaman sangat erat hubungannya dengan total asam. Semakin tinggi total asam pada buah maka $\mathrm{pH}$ buah-buahan akan semakin rendah (makin asam), demikian juga sebaliknya. Total asam minuman fungsional labu kuning yang dihasilkan berpengaruh sangat nyata dari perlakuan konsentrasi sari buah labu kuning dan konsentrasi gula terhadap mutu minuman fungsional labu kuning.
Hasil analisis total asam terhadap minuman fungsional dari labu kuning yang dihasilkan pada tiap perlakuan menunjukkan rentang 1,74-2,86 $\mathrm{mg} \mathrm{KOH} / \mathrm{g}$. Nilai total asam tertinggi diperoleh pada perlakuan perbandingan sari labu kuning dengan air 1:1 dan perlakuan penambahan konsentrasi gula pasir 20\% (A1B3) yaitu $2,86 \mathrm{mg} / \mathrm{g}$, sedangkan total asam terendah diperoleh pada perlakuan A1B3 (perbandingan sari buah dengan air 1:3 dan penambahan konsentrasi gula pasir 10\%) 1,74 mg KOH/g lemak. Kadar total asam pada masingmasing perlakuan dapat dilihat pada Gambar 3.

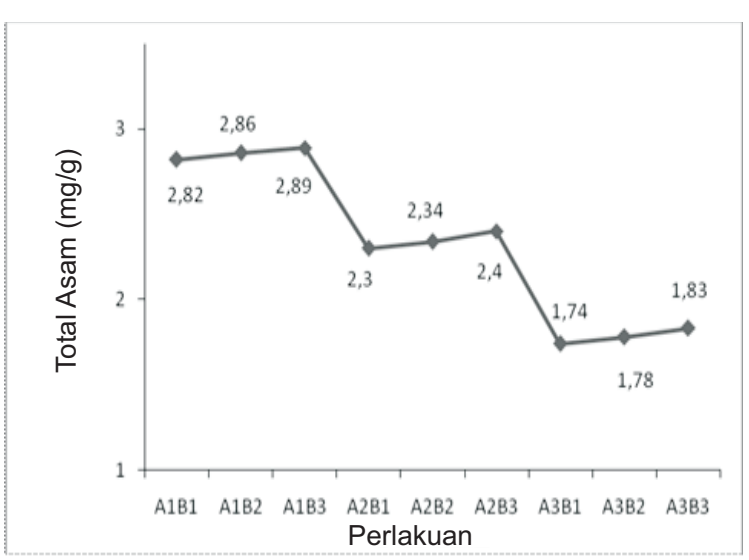

Gambar 3. Pengaruh pengenceran konsentrat sari buah labu kuning dan konsentrasi gula terhadap total asam minuman fungsional labu kuning

Dari Gambar 3 diketahui nilai total asam tertinggi terdapat pada perlakuan A1B3, hal ini diduga karena semakin rendah proporsi buah labu kuning:air (pengenceran sari labu kuning) maka nutrisi yang tersedia semakin melimpah. Dengan adanya fermentasi yang dilakukan, maka waktu yang digunakan oleh bakteri asam laktat merombak gula (glukosa dan fruktosa) menjadi asam laktat dan asam-asam organik. Akibatnya nilai total asam yang dihasilkan tinggi. Sintasari (2014) menambahkan dengan adanya peningkatan jumlah mikroba menyebabkan asam laktat yang dihasilkan semakin besar pula. Hal ini berhubungan dengan aktivitas BAL yang akan merombak sukrosa menjadi asam laktat. Selama fermentasi, laktosa yang terkandung pada susu skim dihidrolisis 
oleh enzim lactase yang dihasikan BAL menjadi asam laktat sehingga terjadi peningkatan nilai total asam karena adanya aktivitas BAL. Berbagai mono-sakarida akan di-metabolisme oleh BAL menjadi glucose6-phosphate atau fructose-6-phosphate. Dengan adanya aktivitas bakteri ini kemudian terjadi metabolisme melalui jalur Embden Meyerhoff Parnas (EMP) atau Heksosa Mono Phosphate (HMP) yang pada akhirnya dihasilkan asam laktat.

\section{Total Padatan Terlarut (TDS)}

TDS adalah ukuran dari jumlah material yang dilarutkan dalam air. Bahan ini dapat mencakup karbonat, bikarbonat, klorida, sulfat, fosfat, nitrat, kalsium, magnesium, natrium, ion-ion organik, dan ion-ion lainnya. Hasil analisat total padatan terlarut dari minuman fungsional labu kuning menunjukkan bahwa semua perlakuan berpengaruh terhadap parameter ini. Adapun hasilnya dapat dilihat pada Gambar 4.

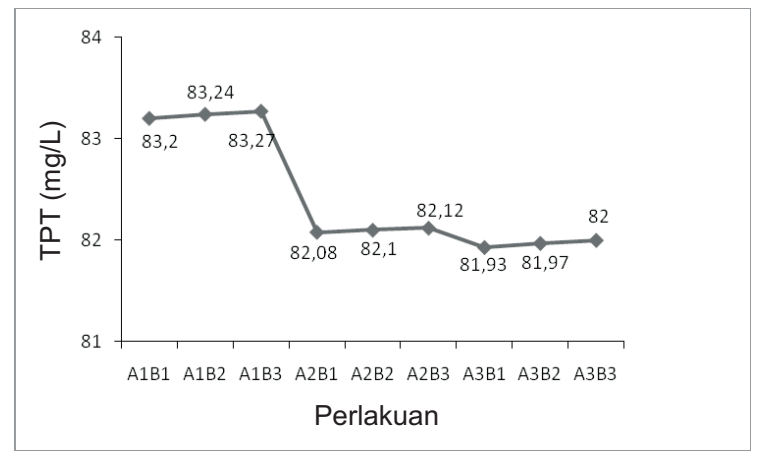

Gambar4. Pengaruh pengenceran konsentrat sari buah labu kuning dan konsentrasi gula terhadap total padatan terlarut minuman fungsional labu kuning

Dari Gambar 4 dapat dilihat bahwa total padatan terlarut tertinggi diperoleh pada perlakuan perbandingan sari buah labu kuning dengan air 1:1 dan perlakuan penambahan konsentrasi gula pasir $20 \%$ (A1B3) yaitu 83,27 mg/l. Total padatan terlarut yang terendah diperoleh pada perlakuan A1B3 (perbandingan sari buah dengan air 1:3 dan penambahan konsentrasi gula pasir $10 \%$ ) dengan nilai $81,93 \mathrm{mg} / \mathrm{l}$.

Dari Gambar 4 diketahui bahwa semakin tinggi perlakuan perbandingan buah labu kuning:air (pengenceran sari buah labu kuning) dan semakin sedikit penambahan konsentrasi gula, maka total padatan terlarut yang dihasilkan semakin rendah. Komponen padatan terlarut terdiri dari pigmen, asam-asam organik, protein dan gula reduksi (glukosa dan fruktosa). Peningkatan total padatan terlarut mengakibatkan terjadinya peningkatan viskositas (Risnawatie, 2004).

Shah (2000) menyatakan bahwa peningkatan pemberian sukrosa pada pangan, menyebabkan jumlah total padatan terlarut (TPT) yang dihasilkan akan semakin banyak pula. Selama proses fermentasi, sukrosa dan laktosa akan dirombak menjadi asam laktat oleh kultur starter dalam jumlah besar. Sisa sukrosa, laktosa dan asamasam organik inilah yang akan terhitung sebagai total padatan terlarut. Asam organik (termasuk asam laktat) merupakan salah satu jenis total padatan terlarut (TPT) selain gula, pigmen, dan vitamin. Total padatan terlarut juga berasal dari penguraian protein menjadi molekul sederhana dan larut dalam air seperti asam amino dan pepton, pemecahan karbohidrat serta pemecahan lemak menjadi asam lemak bebas dan gliserol. Komponen padatan terlarut selain pigmen, asam-asam organik dan protein adalah sukrosa. Semakin lama fermentasi serta semakin lama pemasakan mengakibatkan semakin banyaknya komponen yang terlarut. Hal ini menyebabkan melunakkan jaringan dinding sel akibat penetrasi air ke dalam bahan sehingga semakin banyak molekul padatan yang terekstrak.

\section{Cemaran Besi (Fe)}

Hasil analisa cemaran logam besi $(\mathrm{Fe})$ setelah diuji secara statistik menunjukkan perbedaan yang sangat nyata. Adapun hasil analisa yang diperoleh dari penelitian ini dapat dilihat pada Gambar 5. 


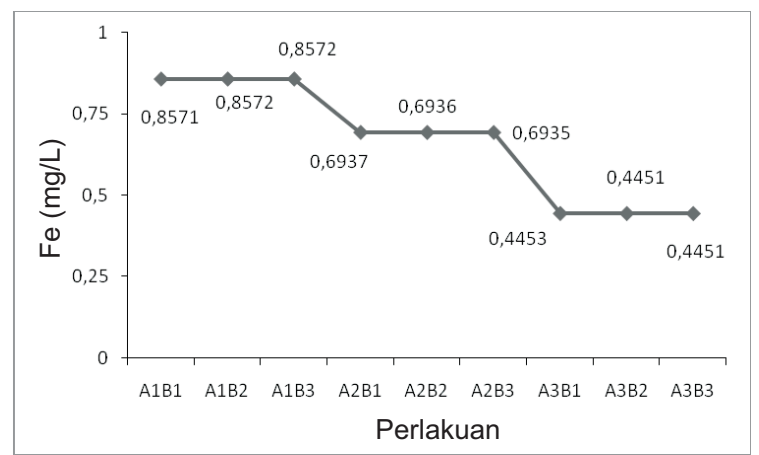

Gambar5. Pengaruh pengenceran konsentrat sari labu kuning dan konsentrasi gula terhadap cemaran besi ( $\mathrm{Fe}$ ) minuman fungsional labu kuning

Berdasarkan Gambar 5 dapat dilihat bahwa nilai kandungan $\mathrm{Fe}$ pada produk berkisar antara 0,4451-0,8571 mg/l. Nilai tertinggi didapatkan pada perlakuan A1B1 (perbandingan sari labu kuning dengan air 1:1 dan penambahan konsentrasi gula pasir $10 \%$ ) tidak berbeda dengan perlakuan A1B2. Sedangkan hasil analisa kandungan Fe didapatkan pada perlakuan A3B2 yang tidak berbeda dengan perlakuan A3B3.

Menurut Rahmawati et al., (2009) zat besi dapat menginisiasi terjadinya peroksidasi lemak dan juga oksidasi protein. Logam Fe dapat menginduksi terjadinya peroksidasi lemak, terutama pada rantai asal lemak tidak jenuh ganda (PUFA). Lemak mengalami oksidasi ini akan menjalani reaksi lanjutan secara berantai membentuk produk radikal bebas seperti radikal alkil, radikal alkoksil, radikal peroksil, dan hidroperoksida. Peningkatan jumlah radikal ini akan mengakibatkan terjadinya dekomposisi asam lemak tidak jenuh menjadi peroksida lemak yang sangat tidak stabil.

Hampir 90\% Fe dalam tubuh hewan berkaitan dengan protein, tetapi yang terpenting adalah ikatannya dengan hemoglobin $(\mathrm{Hb})$. $\mathrm{Hb}$ ini mengandung besi $3,4 \mathrm{~g} / \mathrm{kg}$. Besi juga berperan dalam aktivitas beberapa enzim seperti sitokrom dan flavoprotein. Kebutuhan Fe mengikat jika terjadi pendarahan, dalam konsisi ini, kekurangan $\mathrm{Fe}$ dalam diet mengakibatkan defisiensi $\mathrm{Fe}$, sehingga menimbulkan anemia (Darmono, 1995). Hal ini disebabkan karena meskipun logam Fe masuk kedalam tubuh dan jumlah yang agak berlebihan tidak akan menimbulkan pengaruh buruk terhadap tubuh. Karena unsur Fe dibutuhkan dalam darah untuk mengikat oksigen (Palar, 1994). Diperkirakan bahwa untuk setiap pria dewasa harus memperoleh sekitar $1 \mathrm{mg}$ Fe per hari untuk menggantikan Fe yang diekskresikan melalui saluran pencernaan, urine dan kulit. Pada wanita dewasa, darah yang hilang pada waktu menstruasi perlu diganti dengan 1,4-2,2 mg Fe per hari.

\section{Bakteri Asam Laktat}

Hasil analisa jumlah bakteri asam laktat dapat dilihat pada Gambar 6

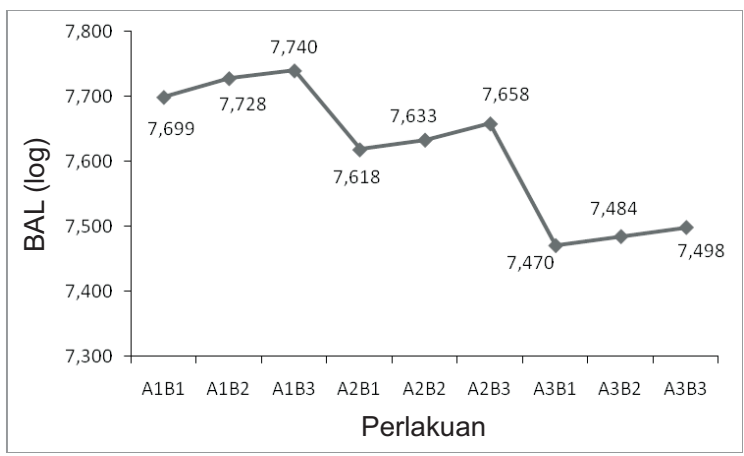

Gambar6. Pengaruh pengenceran konsentrat sari buah labu kuning dan konsentrasi gula terhadap jumlah Bakteri Asam laktat (log) pada minuman fungsional labu kuning

Dari hasil analisis tersebut didapatkan jumlah bakteri yang didapatkan berkisar antara $2,95 \times 10^{7} \mathrm{koloni} / \mathrm{ml}(\log 4,470)$ sampai $5,5 \times 10^{7} \mathrm{koloni} / \mathrm{ml}(\log 7.740)$. Jumlah bakteri asam laktat tertinggi didapatkan pada perlakuan A1B3 (perbandingan sari buah labu kuning dengan air 1:1 dan penambahan konsentrasi gula pasir 20\%). Sedangkan jumlah BAL terendah didapatkan pada perlakuan A3B1. Menurut Mullen (2001) standar minimum bakteri probiotik hidup dalam produk berbasis susu yaitu $10^{7} \mathrm{koloni} / \mathrm{m}$. Pada Gambar 6 terlihat total BAL cenderung meningkat seiring dengan semakin kecilnya 
perbandingan sari buah labu kuning dengan air dan semakin meningkatnya konsentrasi sukrosa yang ditambahkan. Hal ini diduga karena semakin banyak nutrisi yang tersedia dapat mempengaruhi pertumbuhan BAL. Selama proses fermentasi, BAL mampu memecah glukosa, maupun gula lainnya seperti laktosa, galaktosa, fruktosa, sukrosa, dan maltosa menjadi asam laktat (Setyaningsih, 1992). Sehingga berbagai gula baik dari susu skim dan sukrosa dapat dimanfaatkan dengan baik oleh BAL. Nutrisi yang tersedia diduga cukup untuk pertumbuhan bakteri, sehingga pertumbuhan bakteri meningkat. Pertumbuhan bakteri dipengaruhi oleh beberapa hal antara lain nutrisi, temperatur, kelembapan, oksigen, $\mathrm{pH}$ dan substansi penghambat. Sementara menurut Bujalance et al. (2006), Ray \& Bhunia (2008), ada beberapa faktor yang mempengaruhi viabilitas yakni suhu, $\mathrm{pH}$, strain mikroorganisme, kondisi pertumbuhan, umur kultur, media pensuspensi, dan kondisi proses.

\section{Analisis Mikrobiologi}

Pemeriksaan secara mikrobiologi untuk parameter uji bakteri koliform semua perlakuan hasilnya negatif $(<2)$ dan parameter Salmonella negatif. Hasil analisa mikrobiologi yang cukup bagus ini disebabkan terjaganya kebersihan (sanitasi) selama proses pengolahannya. Susiwi (2009) menyatakan bahwa peralatan yang terbuat dari kayu, batu atau plastik harus dibersihkan sebelum digunakan. Selain itu juga harus dicuci dengan sabun bagian luar dan dalam. Kemudian peralatan dibilas sampai bersih dan tidak berbau dan ditiriskan. Program higiene dan sanitasi yang efektif merupakan kunci untuk pengontrolan pertumbuhan mikroba pada produk dan industri pengolahan makanan. Menurut Fachruddin (1998), adanya mikroba dalam suatu produk makanan, akan dapat menyebabkan kerusakan pada makanan tersebut, dimana mikroba tersebut akan memanfaatkan pangan tersebut untuk metabolismenya yang dapat menyebabkan pengasaman dan pembusukan daripada makanan tersebut.

Supardi dan Sukamto (1999) menambahkan bahwa bakteri koliform merupakan flora normal di dalam saluran pencernaan hewan dan manusia yang mudah mencemari air. Oleh karena itu, kontaminasi bakteri ini pada makanan biasanya berasal dari air yang digunakan. Kontaminasi bakteri ini pada makanan atau alat-alat pengolahan merupakan suatu tanda praktek sanitasi yang kurang. Adanya bakteri koliform menunjukkan adanya polusi kotoran pada air yang digunakan. Bahaya terbesar sehubungan dengan produk pangan adalah bila air yang digunakan untuk produk pangan tersebut telah tercemar oleh bahan buangan atau kotoran manusia atau hewan berdarah panas. Bila hal ini terjadi dapat menyebabkan timbulnya penyakit demam usus atau disentri bagi manusia yang mengkonsumsinya. Sedangkan Salmonella adalah bakteri penyebab infeksi, jika tertelan akan menimbulkan gejala yang disebut salmonellosis yaitu infeksi yang menyebabkan diare, demam, muntah dan sakit perut.

\section{Ketahanan Simpan}

Hasil analisa bakteri koliform dari minuman fungsional labu kuning hingga minggu ke-tiga yang disimpan dalam refrigerator menunjukkan hasil negatif yaitu $<2 \mathrm{APM} / \mathrm{ml}$, sedangkan pada minggu keempat, beberapa perlakuan mulai terkontaminasi oleh mikroba jenis ini.

Menurut Winarno (2004) kemampuan mikroba untuk bertahan hidup dan berkembang berkaitan dengan faktor ekstrinsik diantaranya suhu, kelengasan udara, konsentrasi gas dalam lingkungan hidupnya.

Desrosier (1998) menambahkan, pengaruh atau hubungan antara kualitas produk dengan kondisi penyimpanan dipengaruhi oleh beberapa faktor yaitu jenis dan kualitas bahan baku yang digunakan seperti kadar air, zat gizi, metoda keefektifan pengolahan yang menyebabkan seluruh perubahan dalam aseptabilitas produk, jenis dan keadaan pengemasan dan juga pengaruh yang ditimbulkan oleh suhu dan kelembaban penyimpanan. Rahayu et al, (2003), menambahkan bahwa mutu produk pada saat baru diproduksi, dianggap dalam keadaan $100 \%$, dan akan menurun sejalan dengan lamanya penyimpanan atau 
distribusi. Selama penyimpanan dan distribusi, produk pangan akan mengalami kehilangan bobot, nilai pangan, mutu, nilai uang, daya tumbuh, dan kepercayaan.

\section{KESIMPULAN}

Perbandingan sari labu kuning dengan air dan konsentrasi gula berpengaruh nyata pada produk minuman fungsional terhadap semua parameter uji. Hasil optimal didapatkan pada perlakuan perbandingan sari buah dengan air 1:1 dengan konsentrasi gula 20\% (A1B3) dengan nilai $\mathrm{pH} 3,54$, kadar gula $15,85 \%$, total asam $2,80 \mathrm{mg}$ $\mathrm{KOH} / \mathrm{g}$ lemak, total padatan terlarut 83,27 $\mathrm{mg} / \mathrm{l}$ dan cemaran logam $\mathrm{Fe} 0,8572 \mathrm{mg} / \mathrm{l}$ serta jumlah bakteri asam laktat 5,5 $\times 10^{7}$ $\mathrm{koloni} / \mathrm{ml}$. Semua perlakuan tidak mengandung cemaran mikroba baik bakteri koliform <2 APM/100 ml (negatif) maupun Salmonella (negatif). Ketahanan simpan minuman fungsional labu kuning yang disimpan pada suhu $4^{\circ} \mathrm{C}$ (refrigerator) memiliki ketahanan simpan 3 (tiga) minggu.

\section{DAFTAR PUSTAKA}

Anonim. 2012. Tentang Gula Pasir. https://amanmartbak.wordpress.com2 012/08/19/tentang-gula-pasir. Dilihat pada 15 Januari 2014.

Badan Pusat Statistik. 2011. Sumatera Barat dalam Angka. BPS. Sumatera Barat.

Bujalance, C., Valera, M. J., Moreno, E., dan Bravo, A. R. 2006. A selective differential medium for Lactobacillusplantarum. Journal of Microbiological Methods. Vol. 66:572575.

Darmono. 1995. Logam dalam sistem biologi makhluk hidup. Universitas IndonesiaPress, Jakarta.

Desrosier, N., W. 1998. Teknologi Pengawetan Pangan. Penerbit Universitas Indonesia. Jakarta.

Fachruddin, L. 1998. Memilih dan memanfaatkan bahan tambahan makanan. Bogor. Trubus Agriwidya.
FAO/WHO. 2002. Guidelines for the evaluation of probiotics in food. report of a joint $\mathrm{FAO} / \mathrm{WHO}$ working group on drafting guidelines for the evaluation of probiotics in fod. Canada. 1-11.

Muchtadi, D. 2001. Potensi pangan tradisional sebagai pangan fungsional dan suplemen. Dalam I. Nuraida dan R.D. Hariyadi (Ed). Pangan Tradisional Basis Bagi Industri Pangan Fungsional dan Suplemen. Pusat Kajian Makanan Tradisional, Institut Pertanian Bogor, Bogor. 25-34.

Mullen, W., M., A. 2001. Probiotic bacteria. http://www.dairyscience.info/probiotic. htm. dilihat pada tanggal 15 Juni 2014.

Naidu, A., S. and Clemens, R., A. 2000. Natural food antimicrobial system: probiotics. CRC Press. New York. 431462.

Obermen and Libudszis. 1998. Fermented milks. Elselvier Applied Science Pub. New York.

Palar, H. 1994, Pencemaran dan toksikologi logam berat, Rineka Cipta, Jakarta.

Rahayu, W., P., Nurwitri, C., C., Nuraida, L., Hariyadi, R., T. 2003. Mikrobiologi pangan. Jurusan Teknologi Pangan dan Gizi, Fateta IPB.

Rahman, A. 1989. Pengantar teknologi fermentasi. Pusat Antar Universitas Pangan dan Gizi. IPB. Bogor.

Rahmawati, S. dan Sarbini, D. 2009. Uji praklinik: efek fortifikasi $\mathrm{Fe}$ dan $\mathrm{Zn}$ pada biskuit tempe-bekatul terhadap kadar hemoglobin dan albumin mencit yang kurang gizi dan anemia. Jurnal Penelitian Sains dan Teknologi 10(2): 139-147

Ray, B. and Bhunia, A. 2008. Fundamental food microbiology $4^{\text {th }}$ edition. CRC Press, Taylor \& Francis Group. United States of America. 
Retnowati, P.A dan Joni, K. 2014. Minuman Probiotik Sari Buah Kurma. Jurnal Pangan dan Agroindustri Vol.2 No.2 p.70-81, April 201476

Rezawidya. 2011. Konsep minuman fungsional sebagai solusi cerdas membentuk masyarakat modern yang sehat. dilihat pada 23 Januari 2013.

Risnawatie, N., D. 2004. Pembuatan minuman probiotik sari ubi ungu Jepang (Ipomea batatas var. ayamurasaki) kajian $\mathrm{pH}$ pelarut ekstraksi dan lama fermentasi. Skripsi. Teknologi Hasil Pertanian. Fakultas Teknologi Pertanian. Universitas Brawijaya. Malang.

Roberfroid, M., B. 2002. Functional foods: concepts and application to inulin and oligofructose. Universite Catholique de Louvain, Brussels, Belgium. roberfroid@pmnt.ucl.ac.be.

Rusilanti. 2006. Menu bergizi untuk ibu hamil. Cetakan I. Jakarta. Kawan Pustaka

Setyaningsih, I. 1992. Pengaruh jenis kultur L. Casei. Penambahan susu skim dan glukosa terhadap mutu yakult kedelai. Skripsi Fateta. IPB. Bogor.

Shah, P., Nagendra. 2000. Probiotics bacteria: Selectiveenumeration and survival in dairy foods. Journal Dairy Science 83:894-907.

Sintasari, R., A., Joni, K., dan Dian, W., N. 2014. Pengaruh penambahan konsentrasi susu skim dan susu sukrosa terhadap karakteristik minuman probiotik sari beras merah. Jurnal Pangan dan Agroindustri Vol.2 No.3, 65-75, Juli 2014.
Suprayatmi, S. 1996. Yang Manis Tidak Selalu Manis. http.// www. Pagandan Gizi. co. id. Cybernews 18 Juli 1996

Supardi, I., Sukamto. 1999. Mikrobiologi dalam pengolahan dan keamanan pangan. : Alumni Bandung .

Sushanty, D. 2013. (dilihat pada 26 September 2014)

Susiwi, S. 2009. Penentuan kadaluwarsa produk pangan (Hand Out). Jurusan Pendidikan Kimia FPMIPA UPI Bandung.

Widayati, E., dan Damayanti. 2000. Aneka panganan labu kuning, Trubus Agrisarana, Surabaya.

Widowati, S., dan Misgiyarta. 2003. Efektivitas bakteri asam laktat (BAL) dalam pembuatan produk fermentasi berbasis protein/susu nabati. Prosiding Seminar Hasil Penelitian Rintisan dan Bioteknologi Tanaman. Balai Penelitian Bioteknologi dan Sumberdaya Genetik Pertanian. 360373.

Winarno, F., G. 2004. Keamanan pangan. MBrio Press. Bogor.

Yuliani, S., Purwani, E., Y., Setiyanto, H., Usmiati, S., dan Raharto, P. 2003. Pengembangan agroindustri aneka tepung dari bahan pangan sumber karbohidrat lokal: Kegiatan Penelitian Labu Kuning. Laporan Akhir. Balai Penelitian dan Pengembangan Pascapanen Pertanian, Badan Penelitian dan Pengembangan Pertanian, Departemen Pertanian. 